\title{
Improving Student's Listening Skills through (TPS) Text Prediction Strategy by QR-Code Scanning Activity
}

\author{
Putu Agus Primandana \\ SMPN 3 Selat, Karangasem, Bali, Indonesia \\ tuprims@gmail.com
}

\begin{abstract}
This study is aimed to improve the student's listening skills through (TPS) text prediction strategy by QR-code scanning activity. The method of analyzing data in this research is to use the classroom action research study conducted using 2 circles. The subjects of the study were in SMPN 3 Selat, to the ninth students of the first semester in academic year 2019/2020 which consist of 32 students with 15 male and 17 female. This study dealt with TPS (Text Prediction strategy by QR-Code scanning activity to improve students' listening skills. The steps were planning, action, observation, reflection. After the series of action research in teaching and learning process in cycle I and cycle II by using the (TPS) text prediction strategy by QR-code scanning activity to increase student's listening skills of narrative text, the researcher could take some result as follows: there are significant differences we can see from the result of the study before the action and after the action, even in cycle I and cycle II activity. In cycles, the student's minimum completeness rises from 11 students to 25 students from before cycles. After cycle II, the student's minimum completeness is raising also to 29 Students from 25 students who passed the minimum completeness in cycle I. The number of students who still failed in reaching the minimum completeness in cycle II is only 3 students. this may be observed deeply again in the next research to find out the factors and causes about the students who still having trouble mastering listening skills.
\end{abstract}

Keywords: listening, text predictions strategy, QR-Code

\section{Introduction}

The ability in mastering English is important for students to prepare themselves facing global society. Anderson (2008) states that the ability to express their idea and feeling in 4 basics English skills in communication like listening, speaking, reading, and writing is the focus to learn by students in school, the goal is students have the competence to use the ability to communicate in English. The student's receptive skills like listening and reading, and student's productive skills like speaking and writing are the ability which teaches in teaching and learning activity and after that, they can use it in their real life of communication.

Ministry of Education and culture is developing the curriculum which teaches the 4 basic skills of English. Especially in Junior high school grades, students should master Expression, Functional text, monologue, and essay text material. In learning essay text such as Descriptive text, Recount Text, Narrative Text, and Report Text, the students should understand the text in spoken and written. But in fact, the students in junior high school still have trouble listening to some Essay 
text and understanding it well. Based on the researcher's experience in teaching essay text in Junior high school SMP Negeri 3 Selat, Karangasem, the students are still low in understanding the text in the listening activity. This we observed by the score of the student's evaluation in Narrative Text Material in class Ninth-A. From 32 students, only 11 students or $34,3 \%$ students which reach the completeness criteria (KKM) and 21 students or $65,6 \%$ are failing in passing the completeness criteria (KKM), the highest score is 74 and the lowest score is 20 with the average score are 32. Based on the student's interview result at the beginning of this research, there are some factors that make the students feel difficult to understand the text through listening activities : (1) the less of vocabularies that students know, (2) the student's unfamiliar with listening or often practice listening. (3) the lack of students' motivation in listening activity (4) the teaching method which only asks the student to listen and after that giving a question without reviewing and revising.

According to the data above, the researcher tough that there was a problem with the teaching-learning process in practicing listening activity. The teacher seems like using a limited strategy and variation in teaching. That makes the student feel bored in learning; moreover, the teacher never uses an interesting media integrated into the teaching-learning process that makes the students interested and growing up students' motivation in learning. The activity in teaching listening is just the activity in listening to a text in one or two repetitions and after that, the students are giving various questions related to the text and try to answer it. That also makes the students still having low understanding because the students already feel that this difficult and then finally giving up. In the listening activity students need to prepare their vocabulary, understanding the topic, and then try to revise the text. The teacher should prepare a plan and step by step of listening activity that accommodates the creativity, and critical thinking of the students to make the students easy to understand what they are listening and the goal of the teaching-learning process can be reached the maximum.

One strategy that can be used in teaching listening is the use of (TPS) text prediction strategy by QR-Code scanning activity. This strategy can be a solution to make listening activity in class to be more interesting and integrated with the activity to explore digital literacy by using multimedia (TIK); moreover, the students also practicing their higher-order thinking skill (HOTS) with collaboration, critical thinking, communication, and creativity. The aim of the study is: (1) for students to improve students listening skills by through (TPS) Text Prediction Strategy by QR-Code Scanning, (2) for the teacher to know about one innovative strategy in teaching listening and can motivate students during the teaching-learning process (3) to school for increasing the quality of the teaching-learning process in school. 
The hypothesis of this study is the uses of TPS (Text Prediction Strategy) by QR-Code scanning can improve the student's listening skills of the Narrative Text of Ninth grade student of SMP N 3 Selat in academic year 2019/2020.

\section{Research Problem}

On the line of the aspect of the study being investigated the students should improve their listening ability to achieve communicative competence. Due to the relation to the improvement of skill in the teachinglearning process, the researcher decided to apply classroom action research that involved the student under study. So the research question can be formulated as follows: "to what extent can the ninth A grade student's listening skills can be improved through (TPS) text prediction strategy by QR-code scanning activity?

\section{The Objective of the Study}

The objective of the present study is intended to improve the student's listening skills through (TPS) text prediction strategy by QRcode scanning activity.

\section{Underlying Theories \\ Classroom action research}

Bogdan \& Biklen (1992: 223)

explain that action research is the systematic collection of information that is designed to bring about social change. In addition, (Cameron-Jones: 1983) defines action research as research carried out by practitioners with a view to improve their professional practice and understand it better. In accordance with that Allwright and Bailey (1991: 2) mention that it is a research center on the classroom, and simply tries to investigate what actually happens inside the classroom. It treats classroom interaction as virtually the only object worthy of investigation.

Action Research is a process in which educators examine their own practice systematically and carefully using the techniques of research. Participants design a research question, collect data throughout the year, analyze what they have learned, and write about their findings. Observations, interviews, surveys, and journals are typical data methods that participants use to investigate their questions.

The step-in action research is as mentioned in the introduction, a classroom action research is done through a cycle and is designed into four steps. Kemmis and Taggart (1988) state that the research is started by planning for action. Then the plan is implemented as an action in the classroom and the action is then observed. The reflection is done to analyze the data obtained during the action.

CAR is well known for its cycle, namely, planning, action, observation, and reflection. The cycle can be two or three and it usually ends when the researchers have are satisfied or happy with the results. The cycle of CAR can be described as follows: 


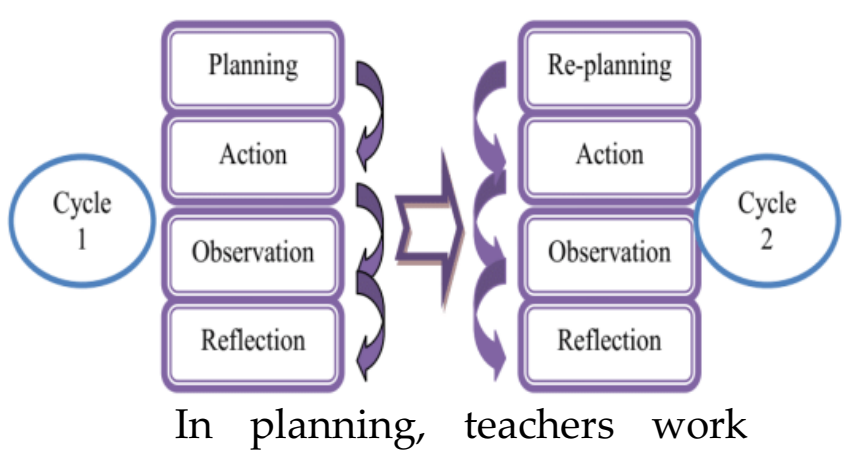

collaboratively on the problems and what is best to do to solve the problem. At this step, they meet to decide everything dealing with the implementation of the teaching and learning process. They decide who will teach what, where, when, and how. They also decide who will do the observation, what instruments to use, and how the observation is done. After having a good plan, the teachers then do the action, meaning that one teacher does the action (the teaching and learning process) while the collaborative one(s) is (are) doing the observation using the instruments determined in the planning step. The action should be in accordance with the plan. The observation is intended to collect data determined in the planning session. The observation is usually focused on the teachers' teaching, the students' learning, and the interaction between the teachers and the students. After the teaching and learning process, the teacher and the observer conduct discussion (reflection) based on the data collected during the implementation of the teaching and learning process. The data should cover all agreed components of the teaching and learning process. They will discuss how the teacher teaches, how the students learn, and how the teachers handle the class. The result of the reflection will determine whether the next cycle should use the same action with some revisions or new action must be done to replace the previous cycle. At the end of certain cycles, it is time to write a report of the research. It means that the researchers must end the research with the research report.

\section{Listening skills}

Listening comprehension is an important part of language learning. Learners want to understand native speakers and a lot of multimedia like DVDs and the Internet. Listening is a significant skill to develop in second language learning (Rost, 2001; Vandergrift, 2007; Kurita, 2012). According to Rost (2001) and Kurita (2012), a major difference between more successful and less successful learners is related to their ability to use listening as an instrument of learning. Listening skill is very important in foreign language learning because the key to learn a language is to receive language input. According to Krashen, Terrell, Ehrman, and Herzog (1984) and Hamouda (2013) acquisition happens when learners have sufficient comprehensible input. Rost (1994) stated that listening is significant in language learning because it provides input for learners and it plays an important role in the development of learners' language. According to Krashen (1985) and Hamouda (2013), listening skill is an important element in obtaining understandable input. Learning will not occur if there isn't any input. Hasan (2000) and Hamouda (2013) expressed that listening comprehension provides the 
appropriate situations for the acquisition and expansion of other language skills. Rost (2002) expressed that the development of listening is related to the attainment of proficiency in speaking. He continued that listening is the most important skill in language learning because it is the most widely used language skill in normal daily life. The listening comprehension process provides beneficial intuitions in teaching listening. Learners may find listening comprehension skills difficult to learn and this can also provide teachers with opportunities to change their listening exercises into more effective ones. Developing listening comprehension skills helps learners to succeed in language learning to enhance comprehensible input. Since learners' self-reliance in listening comprehension will be increased, they will be motivated to have access to spoken English such as conversations with native speakers (Kurita, 2012).

\section{Text Prediction Strategy}

Prediction is a pre-reading activity. According to Smith (1994), the prediction is the prior elimination of unlikely alternatives. It is the core of reading. All of our prior knowledge of places and situations enable us to predict when we read and thus to comprehend and enjoy what we read. The strategy used by English teachers in teaching reading must be adjusted to the kinds of reading text, for example, procedure, descriptive, argumentative, and narrative text. Among the texts which are mentioned above the researcher concerned about descriptive text, because the students were easier inactivate their background knowledge when the prediction strategy applied. Padmadewi (2017) states that prediction or looking to the future is a basic strategy to use the knowledge to understand the text. The students are asking to make a hypothesis about the kinds, goals, and general about the text and then make a transaction to make a confirmation. Prediction about what is going to be listening is a strong base to make students listen in detail because they want to prove their prediction. If the prediction is not corresponding with the real text, it means probably students not having enough initial knowledge. This will make students to be motivated to do better in the next listening activity. Hence, if the students can predict in good accuracy what they going to listen to, the listening activity will be more efficient. The ability to predict is depending on the initial knowledge which is content or languages. That's why; developing the ability in predicting is the first step from listening to English activity.

The effectiveness of text prediction strategy is described as follows: (1) practicing the initial knowledge about the topic which can make they are familiar and closer with the topic which they going to listen, (2) informing the new words and phrases from the text and make the students ready and it will make the text is easier to understand, (3)making the questions about the text become easier to be answered because they can listen effectively and they really 
know what they listened about. (4) Makes the student's mind active and busy, which will make decrease the boring and sleepy feeling while they are listening, (5) calming down their neuron, and make listening activity become effective.

With prediction, students will find that the activity of listening is not boring, otherwise with making and predicting they are going to find a challenge and can smile while they get the right prediction. The important thing that listening activity can be easier than before.

\section{QR-Code Scanning}

QR-Code is a type of matrix barcode (or two-dimensional barcode) first designed in 1994 for the automotive industry in Japan. A barcode is a machine-readable optical label that contains information about the item to which it is attached. In practice, QR codes often contain data for a locator, identifier, or tracker that points to a website or application. A QR code uses four standardized encoding modes (numeric, alphanumeric, byte/binary, and kanji) to store data efficiently; extensions may also be used. (Wikipedia.org)

The Quick Response system became popular outside the automotive industry due to its fast readability and greater storage capacity compared to standard UPC barcodes. Applications include product tracking, item identification, time tracking, document management, and general marketing.

A QR-code consists of black squares arranged in a square grid on a white background, which can be read by an imaging device such as a camera, and processed using ReedSolomon error correction until the image can be appropriately interpreted. The required data is then extracted from patterns that are present in both horizontal and vertical components of the image.

The use of QR-code in learning is really useful. The teachers can easily make QR-code by some applications that consist of the internet. Teachers can generate or fill the QR code with some material of learning, like digital learning media such as some material in Ms. Word, Excel, PPT, link, and many others. Students can scan the WR-Code by their handphones by installing QR-Code Reader applications on their handphones. It's really easy for students to find out the materials in digital form. By using QR-Code scanning activity, students can be more interesting for joined listening activity because they can use their mobile phone which they familiar and usually to support their study at school. They will feel happy and challenged for doing such an activity, rather than just sit down and listen to a text. They will feel bored not interest and sleepy.

\section{Method}

This study uses the classroom action research study (Elliot,1983 and Kemmis et al, 1982) Classroom action research is the research which done by the researcher especially teachers by using some actions that use in their class in order to increase or improve the quality of the teaching-learning 
process or to get a reflection about the teaching-learning process in the class. (Hopkins) states that classroom action research is reflective research about the doing of some actions during the teaching-learning process in class and after that, the researcher can analyze and can find the weaknesses and make a better teaching-learning process later. This study uses 2 cycles of actions. In cycles I the steps are: (1) Planning or arranging the teachinglearning program,(2) Action, or the uses of the method in learning, (3) Evaluation, (4)Analyzing and reflecting.in cycles II the researcher looks at the reflection about the effect of this method or strategy and make a better revision that would be acted in cycles II. This study is held in 3 months from September to the end of November 2019 which divided into two cycles and takes 6 weeks for the cycle I and 4 weeks for cycles II. There were reflections at the end of each cycle.

\section{The Subject of the Study}

This research is held in SMPN 3 Selat, to the Ninth A students of the first semester in academic year 2019/2020 which consist of 32 students with 15 male and 17 female.

\section{The Research Design.}

This Study consistently used classroom action research (CAR) due to its purpose to improve student's listening skills through a certain strategy called (TPS) Text Prediction Strategy by QR-Code Scanning activity. Nunas (1992:75) The research design of this study can be described as follows:

\section{a. Planning}

In this first step, the teacher will arrange the teaching-learning program and administration. This step aims to make sure the learning process is organized well and can reach the aim of the study. The steps of arranging the teaching administrations are

1) Analyzing the standard competence and basic competence of the syllabus of the subject study.

2) Developing the basic competence to the indicator of the study

3) Developing the teaching scenario (RPP)

4) Preparing the materials, and tools needed. (Student's Worksheet, Materials of subject study, multimedia and slide presentation, Speaker, laptop)

\section{b. Acting}

According to the research, the problem states that the students were still having low ability on listening, the hypothesis was concerned that the uses of (TPS) text prediction strategy by QR-Code scanning activity can improve the student's listening skills. The steps for using this strategy are described as follows:

\section{(1) Pre-Listening}

First step: Students were divided into 8 groups which consist of 4 students for each group. The teacher is informing the background of the 
text in which they are going to listen. Teachers are teaching the vocabularies and grammatical reviews related to the text which they going to listen to. They using their handphone to scan the QR-Code which be given by the teacher. After scanning the QR-Code, students will find the material about the words and the grammatical related to the text which they are going to listen to later. The members of each group are discussing the materials directed by the teacher. The students also try to find the difficult word and find meaning in their mother language.

Second step: teachers are driven the students to make a general prediction about (1) the speaker and the aim of the text, the general and specific information of the text.

The third step: the students are trying to make a prediction about: the format about the text the format or the order of the whole text, the keyword or the sentence which they predict that will appear on the text and the information or the opinion of the text.

\section{(2)Whilst-Listening}

On whilst-listening, the students are starting to listen to the text part by part. The text will listen in 2 times for each paragraph and then the teacher will give a chance for students to make predictions for each part until the end part of the text. The teachers will also mentor by giving a question that driven the students to text that they're listening.
(3) Post-Listening

On post-listening, the teacher is helping students to make a synthesis, prediction, and evaluating what they listen about. Each of the student groups will be asked to present their predictions about what they are listening to in front of the class, and the teacher will discuss and identifying about the right and giving the righteousness of the student's prediction. Teacher's also helping the students and asking about what strategy they use when making the prediction and giving some suggestions about how to get better next time listening activity.

\section{c. Evaluating}

To measure the effectiveness of the use of (TPS) text prediction strategy by QR-Code scanning activity in improving the listening skill of Narrative text, the assessment is used to know the understanding of the students about the narrative text they listen to. After the listening activity, the students are given the worksheet (LKS) consisting of some questions related to the text to measure their understanding of the text.

\section{d. Reflecting.}

In reflecting, the result of the measurement is analyzing from the successes and the weakness of the implementation of the strategy in the first cycle has effected the action that going to take in the second cycle. In the first cycle, the result of the student's understanding of the narrative text by using the TPS 
strategy is not maximum; the increase of the student's skill can be seen from the score of evaluation after listening activity in table below:

\begin{tabular}{|l|l|l|l|l|}
\hline Cycles & $\begin{array}{l}\text { Lowest } \\
\text { score }\end{array}$ & $\begin{array}{l}\text { Higher } \\
\text { score }\end{array}$ & $\begin{array}{l}\text { Average } \\
\text { score }\end{array}$ & Enrichment \\
\hline $\begin{array}{l}\text { Before } \\
\text { cycle }\end{array}$ & 20 & 74 & 34 & - \\
\hline $\begin{array}{l}\text { Cycle } \\
\text { I }\end{array}$ & 45 & 84 & 56 & $22 \%$ \\
\hline
\end{tabular}

The reasons for in-maximum increases in student's scores are caused by some factors: (1) the students still unfamiliar with some words that they listen to from the text. Even they are studying some words and difficult words that discuss in the materials, they only know about those words and still confused by the new word that they never know before (2)student's cooperation in the group is not going well because there are some students didn't join and collaborate with the members of the group. Only the leader in the group working active and the other is still passive. (3) the students never practice listening by this strategy, so they still adapting themselves and try to practice listening it seems like students need more listening practice to make them familiar in the listening activity. (4) the student is still shy to present their prediction in front of the class because they feel not confident to express their opinion about the text which they are listening.

According to the data in cycle I, the researcher designs the activity in cycle II to make the improvement of student's listening skills growing up. The steps and strategy in cycle II seem like in cycle I which are: Planning, Acting that consist of (Pre-listening, whilst-listening, and post-listening), Evaluating, and Reflecting. The topic of the text is still a Narrative text about the fable. There are some changes in pre-listening activity in cycle II which, students are giving more time and discussion to find the meaning of the difficult word. The repetition of the text playing is added from 2 times into 3 times, this chance is aimed to give more time for students to discuss and make a better prediction. The teacher also giving more mentoring and facilitating, by joining in each group to give motivation and support for passive members of the group to make more collaborative and cooperative during the activity.

\section{The Finding and Discussion}

After the series of action research in teaching and learning process in cycle I and cycle II by using the (TPS) text prediction strategy by QR-code scanning activity to increase student's listening skills of narrative text, the researcher could take some result as follows: there are significant differences we can see from the result of the study before the action and after the action, even in cycle I and cycle II activity, there was student's score improvement as we can see in the table below: 


\begin{tabular}{|l|c|c|c|c|}
\hline Cycles & $\begin{array}{l}\text { Lowest } \\
\text { score }\end{array}$ & $\begin{array}{l}\text { Higher } \\
\text { score }\end{array}$ & $\begin{array}{l}\text { Average } \\
\text { score }\end{array}$ & $\begin{array}{l}\text { Enrichment } \\
(\%)\end{array}$ \\
\hline $\begin{array}{l}\text { Before } \\
\text { Cycle }\end{array}$ & 20 & 74 & 34 & - \\
\hline $\begin{array}{l}\text { Cycle } \\
\text { I }\end{array}$ & 45 & 86 & 56 & $22 \%$ \\
\hline $\begin{array}{l}\text { Cycle } \\
\text { II }\end{array}$ & 60 & 100 & 74 & $18 \%$ \\
\hline
\end{tabular}

Based on the data above the student's listening skills score before the cycle is 34, after cycle, I held the average score is increase into 56 the lowest score in cycle I increased from 20 before the cycle, to be 45 after cycle I. the higher score also increases from 74 before cycle and become 84 after cycle I. The student's score enrichment is $22 \%$. In cycle II, the average score of student's listening skills is increasing into 56 with the higher score is 84 and the lowest score is 45 and the enrichment of student's scores in cycle II is $18 \%$. The significant of the action we can see also in the number of student's reaching the Minimum completeness of mastery learning (KKM) as we can see in the table below:

\begin{tabular}{|c|c|c|c|c|c|}
\hline \multirow[t]{2}{*}{ Cycles } & \multirow{2}{*}{$\begin{array}{l}\text { Standard } \\
\text { Competen } \\
\text { ce }\end{array}$} & \multirow{2}{*}{$\begin{array}{l}\text { Passing } \\
\text { minimum } \\
\text { completene } \\
\text { ss }\end{array}$} & \multicolumn{3}{|c|}{$\begin{array}{l}\text { The reach of student's minimum } \\
\text { completeness }\end{array}$} \\
\hline & & & $<71 \%$ & $71-85 \%$ & $\begin{array}{l}86- \\
100 \%\end{array}$ \\
\hline $\begin{array}{l}\text { Before } \\
\text { Cycle }\end{array}$ & KD.8.2 & 71 & 21 & 11 & - \\
\hline Cycle I & $\mathrm{KD}$ & 71 & 7 & 19 & 6 \\
\hline Cycle II & KD8.2 & 71 & 3 & 23 & 6 \\
\hline
\end{tabular}

With this table above there were enrichment of the students who passed the minimum completeness of mastery learning (KKM) from before cycles, after cycle I and also in cycle II. In cycle $\mathrm{I}$, the student's minimum completeness rises from 11 students into 25 students from before cycles. After cycle II, the student's minimum completeness is raising also to 29 Students from 25 students who passed the minimum completeness in cycle I. The number of students who still failed in reaching the minimum completeness in cycle II is only 3 students. this may be observed deeply again in the next research to find out the factors and causes about the students who still having trouble mastering listening skills.

\section{Conclusion}

Clearly, the strategy had increased their ability to the listening text which can be recognized from gradually increasing scores. This upgrading score can be found in the grand mean score in cycle I and II. The 
higher score of pre-test or IR of the ninth-A grade students in SMP Negeri 3 Selat was only 74 by 11 students. This rate means the ability of student's listening skills is still low. It was recognized that the strategy works effectively due to the result of the post-test in cycle I and cycle II. From reflection to reflection, the main score is gradually improved. The mean score in cycle I was and in cycle II the mean score is 56 The total grand mean from cycle I and II were 74 the upgrading score from cycle I and cycle II was or $40 \%$. From this fact, it was proved that the student's writing ability was considered fairly satisfactory by applying this strategy.

For a summary, by looking out the data from the present classroom action study, and the number of students passing minimum completeness of mastery learning (KKM) which have been raising positively and having improvement, the researcher believe that the activity in using (TPS) text prediction strategy by QR-code scanning could effectively improve student's listening skills for the ninth-A student of SMP Negeri 3 Selat in academic year 2019/2020.

\section{Suggestions}

Encouraging the students to improve their ability in listening must be a priority for English teachers of class Ninth-A SMP Negeri 3 Selat. The teachers should be more creative, active, and innovative in applying appropriate techniques to improve certain skills. The teachers should give more practice and communicative listening activity in order to give students more time to practice listening. With the often listening activity, the student $\mathrm{s}$ consider being more familiar to listen to the English word and also gaining student's nature remembering. The use of the (TPS) text prediction strategy by using QR-code scanning was proved to be very effective. In line with this, the teachers are highly suggested to use this strategy continues to make the listening activity in class become more meaningful and increase the student's understanding and motivation in class. 


\section{References}

Anderson, J. 2008. Practical English LanguageTeaching Reading. New York: McGraw-Hillcompanies References

Allwright, Dick., Bailey, Kathlen M. 1991. Focus On The Language Classroom An Introduction To Classroom Research For Language Teachers. Cambridge: Cambridge University Press

Bogdan, Robert C . Biklen. Sari Knopp. 1992. Qualitative Research for Education An Introduction To Theory and Methods. London: Allyn and Bacon

Cameron-Jone. 1983. A Searching profession? The Growth of Classroom Action Research. Scotland: Moray house College of Education

Cohen, Louis. 1993. Research Methods In Education. London: Routledge Endrayanto, H.Y S, Harumurti Y.W. 2017Rubrick Application for
Students Evaluation, Kanisius, D.I

Yogyakarta.

Julian Hermida from Gwyn Mettetal, "The What, Why and How of Classroom Action Research", JoSoTL Vol. 2, Number 1 (2001). Kessler C. 1992 Cooperative Language Learning, New Jersey: Prentice hall.

Munir, MIT prof. Dr. 2017. Digital Learning.Alfabeta. Bandung

Nunan D. 1991. Language Teaching Methodology. New York: Practice Hall International

Padmadewi Ni Nyoman, Artini, Luh Putu, Agustini Dewa Ayu Eka, 2017 Intoduction to Micro Teaching. RajaGrafindo . Depok

Smith, F. 1994. Understanding reading. Hillsdale, NJ: Lawrence Erlbaum.

Wikipedia, the free encyclopedia. QRCode (www.wikipedia.com) 